Information about the scope of the survey, methodology, explanation of terms and historical notes for this survey may be found in the introduction of the 1998 Manufacturing Profiles, issued December 2000.

Current data are released electronically on Internet for all individual surveys as they become available. Use: http:/ / www.census.gov/ econ/ www/ manumenu.html. Individual reports can be accessed by choosing "Current Industrial Reports (CIR's)," clicking on "Report Number Index;" from the "Industrial Products by Numeric Index," choose the survey of interest. Follow the menu to view the PDF file or to download the worksheet file (WK format) to your personal computer.

These data are also available through the U.S. Department of Commerce and STAT-USA Electronic Bulletin Board by subscription. To access, dial 202-482-3870 and follow the prompts to register. Also, you may call 202-482-1986 or 1-800-STAT-USA, for further information. The Internet address is: www.stat-usa.gov/.

NOTE. Data are now published on the new North American Industry Classification System (NAICS) basis and therefore are not always comparable to the old Standard Industrial Classification (SIC) code. For further information on NAICS, see www.census.gov/epcd/www/ naics.html.

\section{SUMMARY OF FINDINGS}

During 2000, the total value of shipments for communications equipment totaled $\$ 104.4$ billion, an increase of 16.6 percent from the 1999 value of $\$ 89.6$ billion. Shipments of telephone switching equipment totaled $\$ 15.2$ billion, an increase of 10.4 percent from the $\$ 13.7$ billion shipped in 1999 . Shipments of carrier line equipment and nonconsumer modems increased 41.6 percent, from $\$ 9.3$ billion in 1999 to $\$ 13.1$ billion in 2000 . Other telephone and telegraph equipment shipped in 2000 totaled $\$ 29.0$ billion, an increase of 24.6 percent from the $\$ 23.3$ billion shipped in 1999 . Communications systems and equipment increased 9.2 percent, from $\$ 33.3$ billion shipped in 1999 to $\$ 36.4$ billion in 2000 . Shipments of broadcast, studio, and related electronic equipment remained steady at $\$ 4.0$ billion. Alarm systems totaled $\$ 2.8$ billion in 2000 , an increase of 24.2 percent from the $\$ 2.2$ billion in 1999 .
MA334P(00)-1

Current

Industrial

Reports

Address inquiries concerning these data to Investment Goods Industries Branch, Manufacturing and Construction Division (MCD), Washington, DC 20233-6900, or call Richard Hough, 301-457-4823.

For mail or fax copies of this publication, please contact the Information Services Center, MCD, Washington, DC 20233-6900, or call 301-457-4673.

\section{USCEN SUSBUREA U}

Helping You Make Informed Decisions
U.S. Department of Commerce

Economics and Statistics Administration U.S. Census Bureau 
Table 1. Value of Shipments of Communication Equipment, Including Telephone, Telegraph, and Other Electronic Systems and Equipment by Class of Product: 1991 to 2000

[Millions of dollars]

\begin{tabular}{|c|c|c|c|c|c|c|c|c|c|c|c|}
\hline $\begin{array}{l}\text { Product } \\
\text { code }\end{array}$ & Product description & 2000 & 1999 & 1998 & 1997 & 1996 & 1995 & 1994 & 1993 & 1992 & 1991 \\
\hline & $\begin{array}{l}\text { Communication equipment, including } \\
\text { telephone, telegraph, and other }\end{array}$ & & & & & & & & & & \\
\hline 342101 & $\begin{array}{l}\text { electronic systems and equipment....................... } \\
\text { Telephone switching and switchboard }\end{array}$ & $104,388.7$ & $r / 89,556.6$ & $82,176.4$ & $73,587.8$ & $65,608.6$ & $56,362.0$ & $49,598.1$ & $42,113.8$ & $39,501.9$ & $37,821.0$ \\
\hline 342101 & 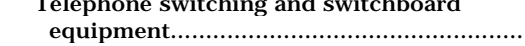 & $15,173.7$ & $13,742.4$ & $12,422.2$ & $10,302.2$ & $9,617.7$ & $8,178.4$ & $8,067.6$ & $7,240.9$ & $7,291.3$ & $6,956.6$ \\
\hline 3342104 & Carrier line equipment and modems............. & $13,112.3$ & $9,263.0$ & $9,378.8$ & $7,278.1$ & $7,544.6$ & $5,868.6$ & $5,114.0$ & $4,993.3$ & $4,810.6$ & $4,298.4$ \\
\hline 3342107 & $\begin{array}{l}\text { Other telephone and telegraph } \\
\text { equipment and components } 1 / \ldots \ldots \ldots \ldots \ldots \ldots\end{array}$ & $28,970.6$ & $r / 23,257.7$ & $19,896.8$ & $16,488.1$ & $14,030.9$ & $10,510.0$ & $8,479.5$ & $7,026.4$ & $5,507.3$ & $4,909.5$ \\
\hline 3342201 & 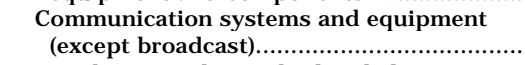 & $36,357.1$ & $r / 33,280.9$ & $31,127.7$ & $29,416.0$ & $25,332.5$ & $23,031.9$ & $19,977.5$ & $16,196.7$ & $15,162.8$ & $14,987.9$ \\
\hline 3342203 & 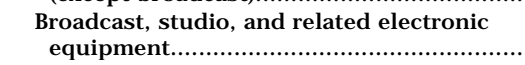 & $4,029.4$ & $r / 3,999.5$ & $3,603.3$ & $3,360.5$ & $3,000.2$ & $2,844.7$ & $2,469.5$ & $2,077.5$ & $1,948.2$ & $1,836.3$ \\
\hline 3342903 & $\begin{array}{l}\text { Intercommunications systems, including } \\
\text { inductive paging systems (selective } \\
\text { calling) }\end{array}$ & 6.8 & $\mathrm{r} /$ & .9 & & & 0 & & & 28 & \\
\hline $\begin{array}{l}3342901 \\
3342902\end{array}$ & 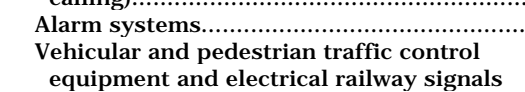 & $2,755.2$ & r/ $2,218.2$ & $2,024.1$ & $1,926.5$ & $1,802.8$ & $1,662.1$ & $1,550.5$ & $1,532.4$ & $\begin{array}{r}288.5 \\
1,370.4\end{array}$ & $1,145.0$ \\
\hline 3333197 & $\begin{array}{l}\text { and attachments..................................................... } \\
\text { Electronic teaching machines, teaching }\end{array}$ & 838.1 & 952.3 & 911.8 & 963.7 & 762.0 & 710.7 & 669.9 & 573.4 & 597.3 & 491.1 \\
\hline & aids, trainers, and simulators.... & 782.1 & 700.7 & 713.0 & 872.0 & 865.7 & 913.3 & & 847.7 & $1,310.8$ & $1,411.0$ \\
\hline 3359997 & Laser sources $2 / \ldots \ldots \ldots \ldots \ldots \ldots \ldots \ldots \ldots \ldots \ldots \ldots \ldots \ldots \ldots \ldots \ldots \ldots \ldots \ldots \ldots \ldots \ldots \ldots \ldots \ldots$ & (S) & (S) & (S) & 991.8 & 843.8 & 787.5 & 726.4 & (NA) & (NA) & (NA) \\
\hline 335999A & Ultrasonic equipment........... & 271.6 & 225.7 & 204.7 & 212.9 & 184.3 & 172.3 & 137.5 & 127.3 & 119.2 & 113.7 \\
\hline 335 & $\begin{array}{l}\text { Other electronic systems and } \\
\text { equipment, n.e.c. }\end{array}$ & $1,651.8$ & $\mathrm{r} / \mathrm{1,515.1}$ & $1,645.1$ & $1,519.7$ & $1,346.3$ & $1,386.5$ & $1,283.5$ & $1,256.5$ & $1,095.5$ & 720.8 \\
\hline
\end{tabular}

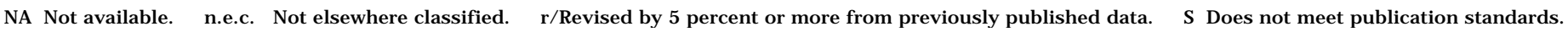

1/Total for product class 3342104 does not include product code 3344184005.

2/Beginning in 1994, data for "Laser equipment, instrumentation, and components" have been eliminated from this survey. Only "Laser sources" are collected. 
Table 2. Quantity and Value of Shipments of Communication Equipment, Including Telephone, Telegraph, and Other Electronic Systems and Equipment by Product Code: 2000 and 1999

[Quantity in number of units. Value in thousands of dollars]

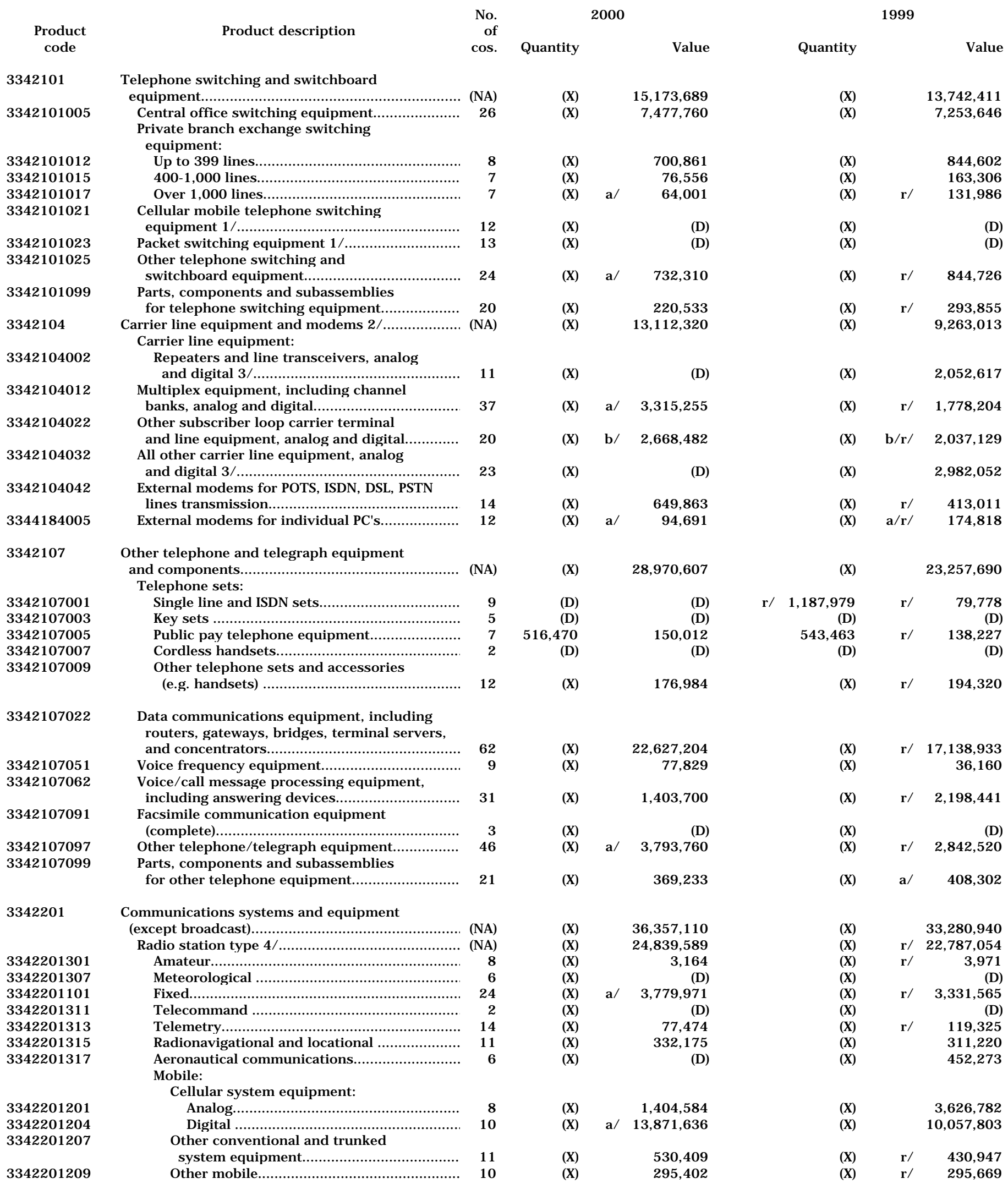


Table 2. Quantity and Value of Shipments of Communication Equipment, Including Telephone, Telegraph, and Other Electronic Systems and Equipment by Product Code: 2000 and 1999

[Quantity in number of units. Value in thousands of dollars]

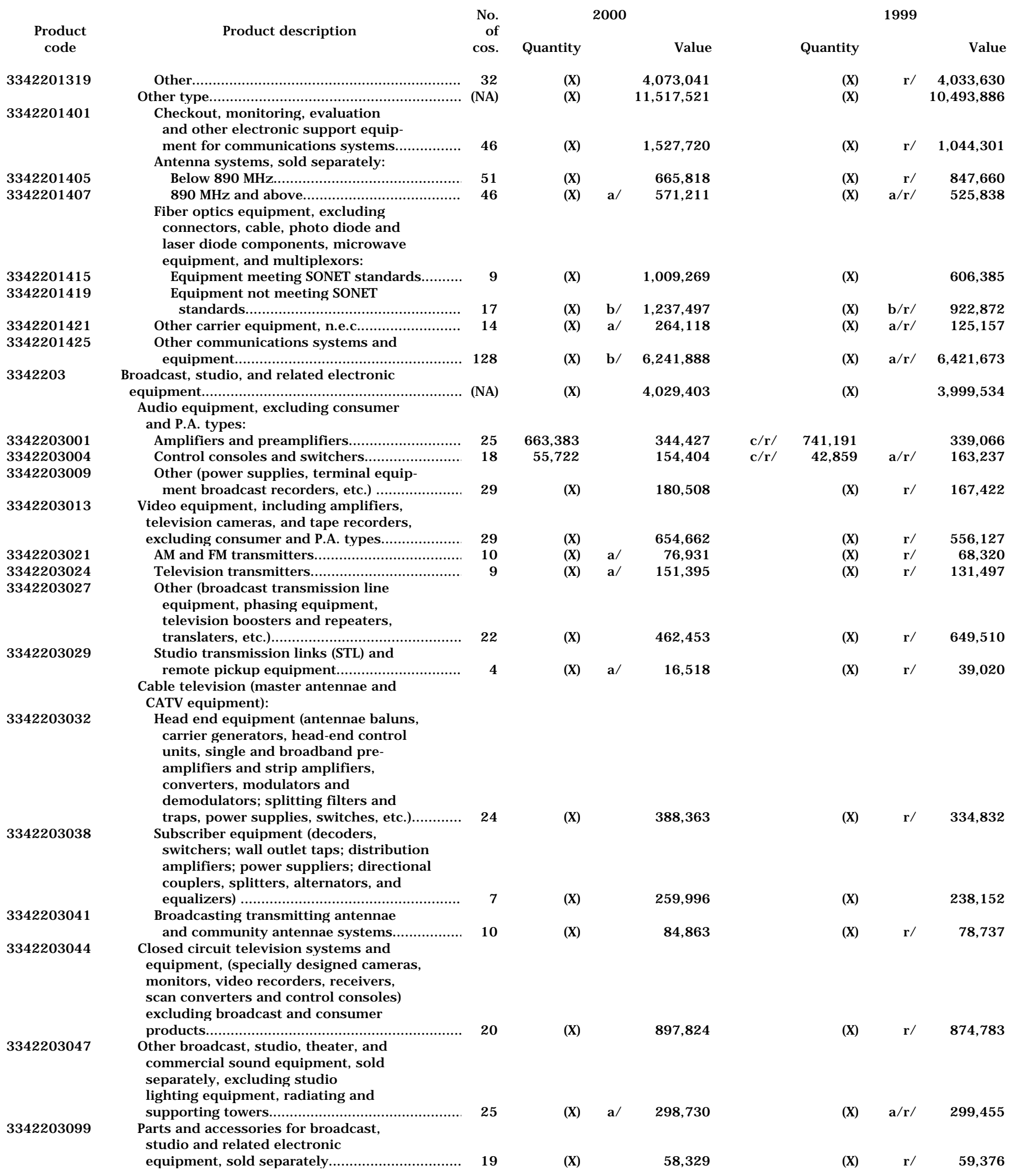


Table 2. Quantity and Value of Shipments of Communication Equipment, Including Telephone, Telegraph, and Other Electronic Systems and Equipment by Product Code: 2000 and 1999

[Quantity in number of units. Value in thousands of dollars]

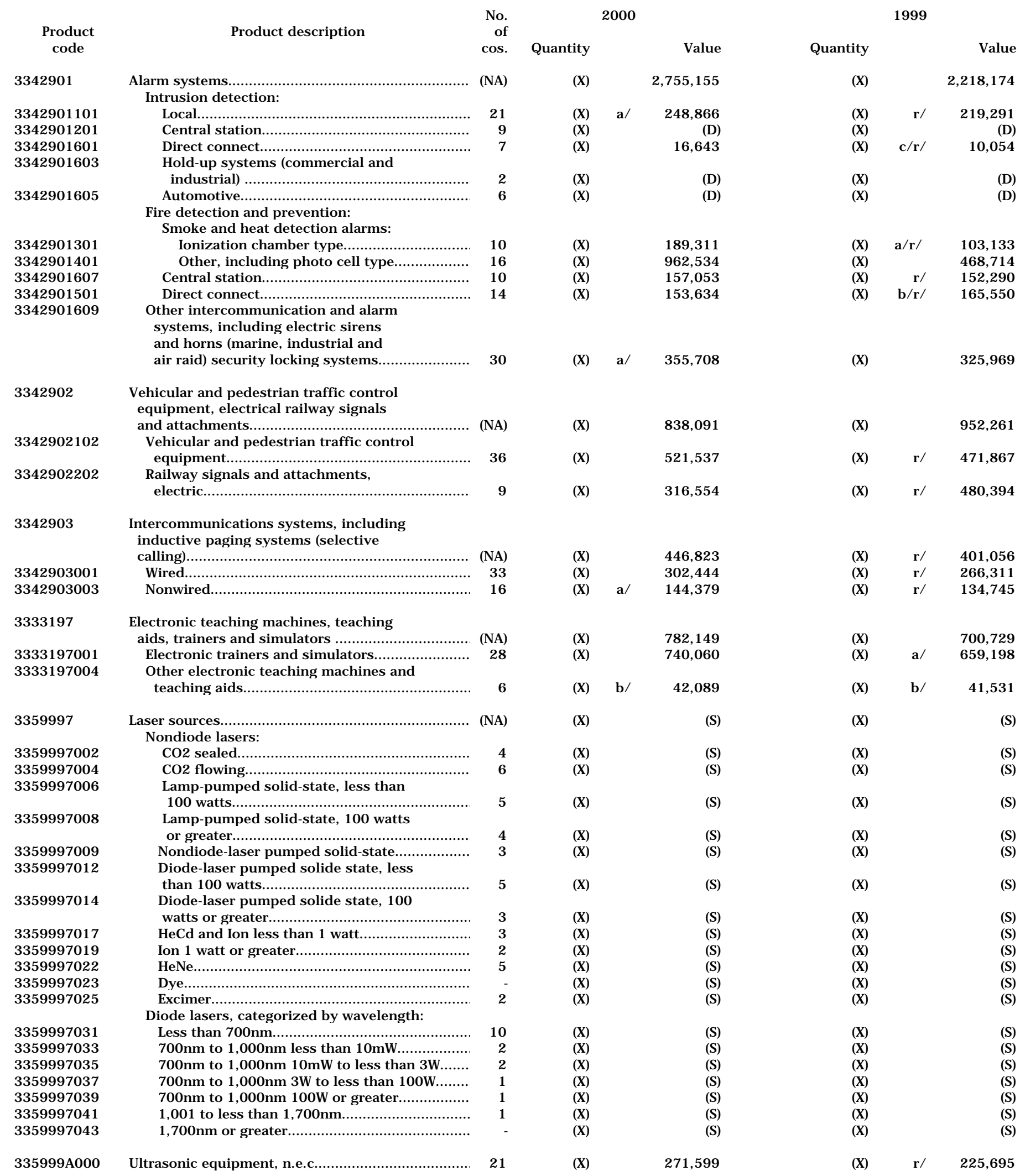


Table 2. Quantity and Value of Shipments of Communication Equipment, Including Telephone, Telegraph, and Other Electronic Systems and Equipment by Product Code: 2000 and 1999

[Quantity in number of units. Value in thousands of dollars]

\begin{tabular}{|c|c|c|c|c|c|c|c|}
\hline \multirow[b]{2}{*}{$\begin{array}{l}\text { Product } \\
\text { code }\end{array}$} & \multirow{2}{*}{ Product description } & \multirow{2}{*}{$\begin{array}{l}\text { No. } \\
\text { of } \\
\text { cos. }\end{array}$} & \multicolumn{2}{|c|}{2000} & \multicolumn{3}{|c|}{1999} \\
\hline & & & Quantity & Value & Quantity & & Value \\
\hline $999 \mathrm{C}$ & $\begin{array}{l}\text { Other electronic systems and equipment, } \\
\text { n.e.c. }\end{array}$ & (NA) & $(\mathrm{X})$ & $1,651.846$ & $(X)$ & $r /$ & $1,515,125$ \\
\hline 5999C001 & Consumer electronic equipment, n.e.c. ................. & 21 & $(\mathrm{X})$ & 482,953 & (X) & r/ & 574,583 \\
\hline $999 C 005$ & Scientific electronic equipment, n.e.c. ……......... & 13 & $(\mathrm{X})$ & 44,127 & $(\mathrm{X})$ & $b / r /$ & 29,337 \\
\hline $5999 C 011$ & Industrial electronic equipment, n.e.c. …............. & 38 & $(\mathrm{X})$ & 283,471 & (X) & $\mathrm{r} /$ & 217,315 \\
\hline 5999C015 & All other electronic equipment, n.e.c................... & 77 & $(\mathrm{X})$ & 841,295 & $(\mathrm{X})$ & $\mathrm{r} /$ & 693,890 \\
\hline
\end{tabular}

- Represents zero. D Withheld to avoid disclosing data for individual companies. NA Not available. n.e.c. Not elsewhere classified. r/Revised by 5 percent or more from previously published data. X Not applicable. S Does not meet publication standards.

1/Product codes 3342101021 and 3342101023 have a combined value of shipments total of 5,901,668 for 2000 and 4,210,290 for 1999 . 2/ Product code 3344184005 is not included in the total for 3342104 .

3/ Product codes 3342104002 and 3342104032 have a combined value of shipments total of 6,478,720 for 2000 .

4/Of this value of shipments total, space based (satellite) accounted for 3.6 billion in 2000 and 3.8 billion in 1999; airborne and marine based accounted for 647 million in 2000 and 624 million in 1999; earth (fixed) based accounted for 4.9 billion in 2000 and 4.3 4.3 billion in 1999; earth (mobile) portable based accounted for 15.7 billion in 2000 and 14.0 billion in 1999.

Note: Percent of estimation of each item is indicated as follows: a/ 10 to 25 percent of this item has been estimated. b/ 26 to 50 percent of this item has been estimated. c/ Over 50 percent of this item has been estimated. 
Table 3. Shipments, Exports, and Imports of Communication Equipment, Including Telephone, Telegraph, and Other Electronic Systems and Equipment: 2000

[Value in thousands of dollars]

Product code

Product description

3342101012, Private branch telephonic exchange

015, 017 switching apparatus

841,418

3342101005 Central office telephonic switching apparatus.

$7,477,760$

$6,633,978$

3342101021, Telephonic switching apparatus, n.e.c.

023, 025

3342101099 Parts components, and subassemblies for telephone switching and switchboard

apparatus...

220,533

(D)

line equipment.

$9,419,202$

3342104012, Carrier line equipment, n.e.c

022,032

3342107001, Telephone sets, including cordless

003, 005, handset telephones

686,974

007, 009

3344184005, Modems, including auxiliary sets

3342104042

3342107022, Telephone and telegraphic equipment,

051, 097

n.e.c., including voice frequency

equipment.

$26,498,793$

$1,403,700$

(D)

(NA)

369,233

344,427

690,779

3342203021, Transmitters, translators, RF power

024, 027 amplifiers, and related equipment.

3342201201, Mobile radio systems and equipment,

204, 207,

209

including tranceivers, and portable

receivers, transmitter and receiver

and receiver, hand held.

$16,102,031$

446,823

3342903001, Intercommunications systems, including

inductive paging systems.

$1,321,183$

$1,546,183$

Exports

of domestic

merchandise

(value at port) $1 /$

145,346

443,426

328,591

$1,087,363$

$3,183,025$

10,025

$4,368,232$

$2,310,973$

653,017

$2,130,546$

$1,121,828$

$2,073,882$

753,399

817,353

36,040

110,407

572,225

$3,760,376$

2,751,099

380,442

343,035

551,600

311,774

3342201405, Antennae systems, including broad-

407, casting, transmitting, and community

3342203041 antennae systems.....

3342203032, Cable television and closed circuit

044, 038 television systems and equipment

including $\mathrm{AM}$ and FM transmitters.
783,899

$7,589,624$

$11,094,202$

50,257

53,722

168,695 
Table 3. Shipments, Exports, and Imports of Communication Equipment, Including Telephone, Telegraph, and Other Electronic Systems and Equipment: 2000

[Value in thousands of dollars]

Product
code

3342901101, Intrusion detection alarm systems

201, 601,

603,605 ,

609

3342901301 Smoke detection alarms, ionization type............

3342901401 Smoke detection alarms, n.e.c., including photo cell type.

3342901501, Central station and direct connect fire

607 detection and prevention alarm systems

3342902102 Vehicular and pedestrian traffic control equipment.

Exports of domestic merchandise (value at port) $1 /$

57,001

12,001

101,267

129,602

107,438

3342902202 Railway signals and attachments, electric.

18,715

7,473

3333197001 Electronic trainers and simulators

335999A000 Ultrasonic equipment, n.e.c.

- Represents zero. D Withheld to avoid disclosing data for individual companies. NA Not available. n.e.c. Not elsewhere classified.

1/Source: Census Bureau report EM 545, U.S. Exports.

2/ Source: Census Bureau report IM 145, U.S. Imports for Consumption. 
Table 4. Comparison of North American Industry Classification System-Based Product Codes with Schedule B Export Numbers and HTSUSA Import Numbers: 2000

Product code

3342101012 , 015,017

3342101005 Central office telephonic switching apparatus.

3342101021, Telephonic switching apparatus, n.e.c.

023,025

3342101099

Parts components, and suba
switchboard apparatus..

assemblies for telephone switching and

Repeaters and line tranceivers, carrier line equipment

Carrier line equipment, n.e.c.

3342104012 022,033

3342107001, Telephone sets, including cordless handset telephones 003,005 007, 009

3344184005 , 3342104042

3342107022 , 051, 098

Telephone and
equipment

Modems, including auxiliary sets

Export number 1/

8517.30 .2000

8517.30 .1500

8517.30 .3000

8517.90 .2000

8518.40 .1000

8517.50 .5000

8517.50 .6000

8517.50 .9000

8517.11.0000

8517.19 .0000

8518.30 .1000

8525.20 .9020

8517.50 .1000

8517.30 .5000

8517.80 .1020

8517.80 .2000

8517.30 .2500

8520.20 .0000

3342107062

Telephone answering devices

3342107091

Facsimile communication equipment (complete)

(NA)

3342107099

Parts, components and subassemblies for other telephone equipment............

Audio amplifiers and preamplifiers, (except consumer and P.A. types)

Transmitters, translators, RF power amplifiers, and related equipment....

3342203021 024,027
8517.90 .5000

8518.40 .2000

8525.10 .6010

8525.10 .6030

8525.10 .6050

8525.10 .6070

8525.10 .6090

8525.10 .8020

8525.10 .8040
Import number 2/

8517.30 .2000

8517.30.1500

8517.30 .3000

8517.90 .2400 8517.90 .3600 8517.90 .5800

8518.40 .1000

8517.50 .5000 8517.50 .6000 8517.50 .9000

8517.11 .0000

8517.50 .1000

8517.30 .5000 8517.80 .1020 8517.80 .2000 8517.30 .2500

8520.20 .0040 8520.20 .0080

8517.21 .0000

8517.90 .1200 8517.90 .3800 8517.90 .5200 8517.90 .6400

8518.40 .2000

8525.10 .2040 8525.10.6020 8525.10 .6040 8525.10 .6060 8525.10 .6080 8525.10 .7025 8525.10.7045 8525.10.7065 8525.10 .8000 8525.10 .9025 8525.10 .9045 8525.10 .9065 8525.10 .9085 8525.10 .9090 
Table 4. Comparison of North American Industry Classification System-Based Product Codes with Schedule B Export Numbers and HTSUSA Import Numbers: 2000

Product code

3342201201 , 204, 207, 209
Product description

Mobile radio systems and equipment, including tranceivers, and portable receivers, transmitter and receiver, hand held.
8529.90 .5000

3342903001, Intercommunications systems, including inductive paging systems 003

3342201405 ,

407 ,

3342203041

Antennae systems, including broadcasting, transmitting, and

community antennae systems...

3342203032 , 038,044

3342901101 201,601 ,

603,605 , 609

3342901301

3342901401

3342901501 , 607

3342902101 , 103

3342902201 , 203

3333197001
Cable TV and closed circuit television systems and equipment including $\mathrm{AM}$ and $\mathrm{FM}$ transmitters

Intrusion detection alarm systems

8531.10 .0025

8530.10 .0000

Railway signals and attachments, electric

Electronic trainers and simulators.
Export number $1 /$

8525.20 .1000

8525.20 .2000

8525.20 .3030

8525.20 .3040

8525.20 .3042

8525.20 .3045

8525.20 .3055

8525.20 .9040

8525.20 .9080

8527.90 .8025

8529.10 .2020

8529.10 .2050

8529.10 .4000

8529.10.6000

8525.10 .2010

8525.10 .2050

8531.10 .0035

9022.29 .4000

8531.10 .0015

8531.10.0045

8530.80 .0000

8530.90 .0000

Import number 2/

8525.20 .0500

8525.20 .1500

8525.20 .2400

8525.20 .2800

8525.20 .3010

8525.20 .3015

8525.20.3025

8525.20 .3040

8525.20 .3060

8525.20 .3065

8525.20 .3070

8525.20 .3080

8525.20 .9020

8525.20 .9060

8525.20 .9070

8525.20 .9080

8527.90 .9020

8529.90 .7600

8529.90 .8500

8517.80 .1010

8531.80 .4000

8529.10.2020

8529.10 .2050

8529.10 .4040

8529.10 .6000

8525.10 .2030

8531.10 .0035

9022.29 .4000

8531.10 .0015

8531.10 .0025

8531.10.0045

8530.80 .0000

8530.90 .0000

8530.10 .0000

8805.20 .0000

8805.20 .0000 
Table 4. Comparison of North American Industry Classification System-Based Product Codes with Schedule B Export Numbers and HTSUSA Import Numbers: 2000

Product

code

Product description

335999A000

Ultrasonic equipment, n.e.c.

Export
number 1/
8456.10 .0000
8456.20 .0000
8479.89 .9585

8479.89 .9585

NA Not available. n.e.c. Not elsewhere classified.
Import number 21

8456.20 .1010 8456.20 .1050

8456.20 .5000

8479.89 .9585

1/Source: 2000 edition, Harmonized System-Based Schedule B, Statistical Classification of Domestic and Foreign Commodities Exported from the United States.

2/ Source: Harmonized Tariff Schedule of the United States, Annotated (2000). 